\title{
Heroes and Villains in Uruguayan Soccer (2010-2014): A discursive Approach
}

Authors' contribution:

A) conception and design of the study

B) acquisition of data

C) analysis and interpretation of data

D) manuscript preparation

E) obtaining funding

\author{
Cristian Maneiro $^{\text {A-E }}$, Wanderley Marchi Jr ${ }^{\text {A-E }}$
}

Universidade Federal do Paraná, Brasil
This paper proposes to discuss, through an individual case study of four athletes, the mechanisms used by the Uruguayan sports press in the discursive construction of national soccer heroes and villains in the 2010-2014 period.

The article begins with a theoretically founded introduction to the processes of media construction of sports heroes and their importance in the socialization process individuals go through in any given society.

Afterwards, a brief case study of the selected athletes is developed in light of this theoretical framework, focusing on the mechanisms used for discursively constructing heroes and their transformations into villains.

Finally, the selected cases are summarized, underlying the media atribution of certain values and features considered socially desirable by Uruguayan society.

sport heroes, mass media, soccer, uruguay

\section{Introduction: Sports Heroes in society.}

Within any temporal or space context that we may place ourselves, life in society requires from its members certain institutionalized behaviors in order to ensure a minimum level of cohesion that enables social reproduction. The process by which members of a society internalize social norms and expected behaviors is commonly referred in literature as the "socialization process" (Berger \& Luckman, 1986).

In the early stages of life, people experience "primary socialization" (Berger \& Luckman, 1986), which occurs within the family and is done by parents, siblings and direct relatives. From childhood on, and throughout the rest of adult life, family gradually loses prominence and other socialization agents emerge (formal education, peer groups, media) that build up the character of the individuals, complementing and even potentially overturning primary socialization in a process known as "secondary socialization" (Berger \& Luckman, 1986), which involves the continuous internalization of sub-worlds of particular meanings.

In this secondary socialization, the mass media presents an increasing level of importance. The social identity of individuals and groups is built, among other agents, upon the messages sent by the media. 
Although each person may incorporate media into their lives in different ways, the things people read, hear, and see in the media are important parts of their daily experience. They frame and influence thoughts, conversations, decisions and experiences around it (Coakley, 2007). Based on this assumption, authors like Dyer (1979) and Jackson (2001) describes the process of "building" media celebrities, which represent ways of acting and thinking that are considered desirable in a given society.

The attributes of a celebrity are built socially and midiatically, and in these terms it can be argued that stars are representations of people that reinforce, legitimate or occasionally alter the prevalent preconceptions of what it is to be a human being in a given society. Stars represents typical ways of behaving, feeling and thinking in contemporary society; ways that have been socially, culturally and historically "constructed" (Dyer, 1979, p. 18).

These celebrities have the characteristic of being able to become a brand in themselves, without needing relevant achievements in their field of action (Jackson, 2001).Taking empirical examples from the music and film industries, Dyer argues that stars are "manufactured" to serve a specific purpose: to make money from audiences who respond to various elements of a star by buying their records and becoming fans. Film and live theater companies tend to manufacture what they think audiences want, and therefore stars are commodities produced and consumed based on the strength of their meanings (Dyer, 1979)

Current characteristics of modern sports regarding its increasing globalization, spectacularization and commercialization enable elite athletes to be representatives of different brands, becoming visible faces for private companies from different industries, some of them acquiring this character of celebrity aimed at ensuring the loyalty of its audiences. As mentioned by Dyer (1979), in some cases the characteristics that have led them to be constructed as celebrities allow these athletes get as much or even more benefits from their stardom (image rights, sponsorship) as they do for their sports performance.

However, elite athletes are often not just celebrities, but in some cases they are atrributed mythical redeeming features of their community. In this sense, soccer, as an agonistic sport, tends to the construction of "heroes" more than music or film industries, which are more likely to produce "stars" (Helal, 2000).

The concept of myth has a long tradition in anthropology. Authors such as Campbell (1997) studied different types of myths in ancient populations describing the beliefs system that conforms them and the rituals by which they are expressed. Our interest in this article is focused on a special kind of myth: the "hero" myth. According to Campbell (1997), we can define a basic unit of the hero myth that is repeated in all cases and it's expressed in a cycle comprising various instances: the departure of the individual from his everyday world, the experience of different thresholds, where he will find unknown challenges that will test his heroic nature, and finally the return, where the hero gets back home with the elixir of victory that will redeem his people, providing experience and wisdom for self-conquest, ending the mythical cycle.

Following Rubio (2001), some characteristics of modern athletes can be compared to those heroes portrayed through myths. Both athletes and heroes face a lonely and journey full of tests to reach their goals. In the case of the athlete, it can be thought that training, and especially concentration, where athletes find themselves away from their family and close relatives (Rubio, 2001).

The life of sports constantly presents a series of tests that those wanting to be heroes must overcome (e.g., bruises, failures, etc.) to qualify them as such. Hero-Athletes play a role in representing their community, and their success can be attributed to the fact that they are able to overcome obstacles that seem impossible for most people. Often, the humble origins of athletes enhance this identification with their community and contribute to forming the character of hero that can overcome these unfavorable initial conditions. Da Matta (1982, p. 199) clearly expresses this when considering the archetype of Brazilian hero:

"We always start with someone very poor and wretched, someone who is down very far in the basement of the social world, and obviously we end up with his withering social mobility. However, and this needs to be well noted, in that character we had poverty and disgrace, but 
never mediocrity or lack of nobility. In fact, the subject was well marked from the beginning of the story for a particular signal, an inescapable feature of his special character", .

Heroic stories are legitimized by achievements and the mystification of subjects as main actors of these victories, which favor the scenario of challenge, battle, pain, drama and reward. However, success is never reached without difficulties. Defeats re-build the subject and provide experience, preparing them for new challenges and giving them strength to fight new conquests. Thus, the hero-athlete learns to persist in the face of defeat and overcome difficulties, which makes him a reference for other individuals (Rubio, 2001).

Nowadays, soccer has a benchmark of conduct in the hero myth. It is presented as a mythical narrative for overcoming obstacles, and the emphasis on effort and hard work as a way to achieve success. The aspiring hero must show perseverance, determination, honesty, courage and altruism to reach and mantain its condition (Rubio, 2001).

Societies produce heroes as exemplary role models through media. The hero-athlete fulfills a social function indicating the path of self-improvement, hard work and a way of confronting the difficulties to achieve success, putting into place a mythical archetype (Campbell, 1997). In this sense, media coverage constructs sports and viewer experiences by portraying sports as a plot where rivalries are hyped up and used to serialize stories through and across seasons; conflict and chaos are highlighted with a predictable cast of "good guys," "bad guys," "heroes" and "redemption" stories (Coakley, 2007). The media, as secondary socialization agents, plays a fundamental role in providing guidelines on ideologies, representations, values and behaviors to be followed by a certain audience. At the same time, the media reflects the ideologies and representations that are operating in their social environment. Thus, consumption and interpretation of celebrities is not an automatic phenomenon. Audiences may accept the proposed heroes or rather question them. The concept of articulation, as used by Kellner (2001), helps us to conceptualize this two-way relationship between the media and its social environment:

\begin{abstract}
"There is a culture conveyed by the media whose sounds and images help to weave the fabric of everyday life, dominating the leisure time, shaping political opinions and social behaviors, and providing the material with which people forge their identity [...]. Cultural studies outline how cultural productions articulate ideologies, values and representations of gender, race and class in society and how these are interrelated. Therefore, to place the cultural texts in their social context implies tracing the joints in which societies produce culture and how culture, in turn, shapes society through its influence on individuals and groups" (Kellner, 2001, p. 39)2.
\end{abstract}

We believe that the importance of this perspective is that it lead us to avoid two simplistic interpretations of media: first, an apocalyptic vision where media is considered an ideological agent, functional to the dominant ideology that seeks to mystify and distort reality according to political or economic interests, and second, the antagonistic posture to evaluate the media and their contents as simple entertainment and having no particular intentions and interests. Without taking sides with any of these

\footnotetext{
${ }^{1}$ Sempre começamos com alguém muito pobre e desgraçado, alguém que está lá embaixo, nos porões do mundo social. E obviamente terminamos com sua ascensão social fulminante [...]. Mas, é este ponto precisa ser bem acentuado, naquele personagem havia pobreza e desgraça, mas nunca mediocridade ou falta de nobreza. De fato, o sujeito estava muito bem marcado desde o início da estória por algum sinal particular, traço iniludível do seu caráter especial, sempre revelado por nós de modo substantivo

${ }^{2}$ Há uma cultura veiculada pela mídia cujas imagens sons e espetáculos ajudam a urdir o tecido da vida cotidiana, dominando o tempo de lazer, modelando opiniões políticas e comportamentos sociais, e fornecendo o material com que as pessoas forjam sua identidade [...]. Os estudos culturais delineiam o modo como as produções culturais articulam ideologias, valores e representações de sexo, raça e classe na sociedade e o modo como esses fenômenos se interrelacionam.Portanto, situar os textos culturais em seu contexto social implica traçar as articulações pelas quais as sociedades produzem cultura e o modo como a cultura, por sua vez, conforma a sociedade por meio de sua influência sobre indivíduos e grupos
} 
interpretations, the author states that only specific empirical studies will determine the character of the media in each case, from an articulation perspective with their social environment (Kellner, 2001).

In the following section we sought to identify, the features of some players that are presented as celebrities and/or heroes by the sports journalismfrom biographies and news pieces, for having different virtues both related to soccer and outside of soccer that were considered socially desirable.

Thus, we will analyze, through individual case studies, the discursive constructions of the most mentioned members of the Uruguayan national team according to the coverage provided by the national sports press, considering all news pieces appearing in the online version of the major Uruguayan sports journal (OVACION DIGITAL) for the period 2010-2014. ${ }^{3}$ Considering the extensive period of time and the difficulty of making a daily follow-up, the focus was on the major soccer events during those four years (World Cup 2010, American Cup 2011; Qualifiers and World Cup 2014) considering all news that appeared in the selected journal on match days, the day before and the day after. The final number of news pieces considered reaches 520. The ranking of most-named athletes in these data is shown in the table below.

Table 1. Players' total mentions and news pieces in Ovacion Digital during 2010-2014 period.

\begin{tabular}{|l|l|l|}
\hline Player & Total Mentions & $\mathbf{N}^{\mathbf{0}}$ of documents \\
\hline O. Tabárez & 1104 & 391 \\
\hline L. Suárez & 1002 & 358 \\
\hline D. Forlán & 623 & 281 \\
\hline D. Lugano & 437 & 225 \\
\hline E. Cavani & 402 & 203 \\
\hline D. Godin & 203 & 124 \\
\hline E. Arévalo & 186 & 141 \\
\hline S. Abreu & 111 & 68 \\
\hline C. Rodríguez & 103 & 58 \\
\hline
\end{tabular}

Source: own study.

The data collection and consequent analysis was done following a qualitative approach, therefore the aim of our work is not to validate the data from a statistical point of view and infer general conclusions, but rather to seek to gain a comprehensive approach that allows us to explore the case studies selected more indepth (Flick, 2004) in the light of the theoretical framework described above.

After choosing the case studies to analyze, we have filtered those articles that were related to these athletes from our available data. In addition, we also considerd a few yearbooks and other special editions of Ovacion Digital and other journals (Revista EL GRÁFICO, Revista El Observador) as well as a national best-seller book that featured in-depth interviews with these and other football players (Lissardy, 2010).

In the following sections, we analyze each one of the cases selected for study, following the theoretical issues discussed.

\footnotetext{
${ }^{3}$ Online content is exactly the same as the printed version, with neither version having exclusive content . The newsfeed is available for open access from 2002 at www.historico.ovacion.com.uy .
} 


\section{Diego Forlán: Behavior model}

Chosen best player of World Cup South Africa 2010 (WC2010) by the Féderation Internationale de Football Association (FIFA), and considered "man of the year" for Uruguayan public opinion surveys. ${ }^{4}$ Diego Forlán is discursively constructed as a sport "hero" because of some particular characteristics.

Contrary to what was theoretically suggested by Da Matta (1982) and empirically verified in many cases (e.g., Garrincha, Romario and Maradona), Forlán is not an example of social mobility or the overcoming of unfavorable situations through sports. Being raised in an upper middle-class family settled in a suburb of Montevideo, his childhood and youth took place in a welfare context different than the difficulties experienced by other athletes.

This stable family background allowed the player to finish high school in private schools, play tennis semi-professionally and study various languages such as English, Portuguese and French (Lissardy, 2010), activities commonly considered elitist and that might not be most common in professional football players, most of whom drop out of formal schooling at some point .

Furthermore, since 2005, Forlán takes a position as a goodwill ambassador of the United Nations Children's Fund (UNICEF), being the frontman of the organization in Uruguay and participating in various campaigns. The press presents him as a humble player, educated and of an above average "cultural level", making him a model for idolization, especially by young people.

"Forlán is the biotype of professional, on which is based on the work of coach Tábarez [...] to show it, here's a revelation: The coach assistant has expressed that the striker is the most well organized of all the group" (EL OBSERVADOR, EL AÑO QUE VOVIO A LATIR LA CELESTE, pp. 5, 2010).

"Doctor Rossi, a psychiatrist specialized in children and adolescents, recalls the exemplary value to young people of some of the players. "It's a team full of people with nice interests [...] for example we have Forlán as an ambassador for UNICEF, so we are talking about positive models for young people," he stated" (OVACION DIGITAL, 07/03/2010).

"Forlán is a first-class player, a social example for youth [...]. hopefully there will be many Forláns in the future with such simplicity and humility" says football director Damiani" (EL GRAFICO, LIBRO DE COLECCIÓN 4, pp 8, 2010).

"Not Messi, nor Cristiano Ronaldo - the world of soccer gave a standing ovation to Diego Forlán. His name was on everyone's lips. Not only for his goals or his electrifying runs, but for his humility" (ANUARIO OVACION, pp 15, 2010).

What determines the sports success of Forlán is an extreme sense of professionalism and constantly renewed desire for personal growth, overcoming the obstacles that test his courage to become a hero, incorporating the wisdom to face future challenges through these experiences (Rubio, 2001).

In this sense, the extra hours spent in training to improve kicking with both legs and professional physical improvement that he does outside regular training schedules are constantly highlighted.

"Simple, serious, gentle, responsible [... ] a leader not because of temperament, but behavior. First in the row of sacrifice, a calm voice that is heard among the team, a symbol of a new generation" (EL GRAFICO LIBRO DE COLECCIÓN 4, pp 9, 2010).

"Born with a history and a mission of perseverance and excellence. With that history in his veins, Diego prepared himself since childhood to develop his full potential. He practiced every

\footnotetext{
${ }^{4}$ Results of these surveys can be verified at HTTP://WWW.MONTEVIDEO.COM.UY/NOTNOTICIAS_127557_1.HTML or : http://medios.elpais.com.uy/downloads/2011/cien_x_cien.pdf Accessed on: April 1, 2014.
} 
day with a ball against a wall, one leg to another, one after the other, to develop the same power in both" (Lissardy, 2010, pp. 140-144).

"Forlán used adversity as motivation, the preparation matches showed him being away from the adversary net and even imprecise with the ball [...]. Forlán overcame the problems in his club, the scrutiny of his private life and questioning of his scoring drought" (ANUARIO OVACION, pp 12, 2011).

"The success of the blonde from Atlético de Madrid is not the result of chance. It is the result of a lifestyle. He is harnessing the opportunities that his sports career offers and knowing how to take fair and opportune steps" (EL OBSERVADOR, EL AÑO QUE VOVIO A LATIR LA CELESTE, pp 23, 2010).

His performance in the WC2010 consecrated Forlán's career, who was also living a great moment in his club, Atlético Madrid, where he won the UEFA Europa League and obtained the European Golden Boot in the 2009-2010 season. In the American Cup Argentina 2011 (AC2011), he also had a good performance and his two goals in the final made him top scorer of the national team at the time.

However, since the second half of 2011, long periods of inactivity and low performances at his clubs (Inter Milan and Internacional de Porto Alegre) during 2012 and 2013 also led to a sharp decline in performance on the national team.

This negative performance, even though it does not affect his media construction as a role model, promotes criticism about his playing style and constant question of his place on the national team by journalists and former players interviewed.

"Forlán scored, but it was his only contribution. He was slow, uncertain and imprecise with the ball. He lost many passes” (OVACION DIGITAL, 06/03/2012).

"The Forlán we know still does not appear. He did not make a single shot. He missed a very clear goal situation" (OVACION DIGITAL, 10/17/2012).

"Uruguay collapsed, individuals do not appear. Decisive players are needed, as Forlán was in the World Cup, but now he is in very poor form” (OVACION DIGITAL, 10/17/2012).

"We must change [...] place Cavani on the forward with Luis Suárez [...]. Forlán cannot continue" said Fabian O'Neill” (OVACION DIGITAL, 10/17/2012).

A turning point in the discursive construction on Diego Forlán took place after the defeat against Chile in Santiago, where he was photographed smiling and exchanging his shirt with a rival. This act, though consistent with the attitude expressed by the player in several interviews to "de-dramatize" soccer and understand it as a job (Lissardy, 2010), was widely criticized on social networks, interpreting it as a "lack of commitment" to the team.

"Forlán, a few hours before had appeared in television images exchanging his shirt with a rival and smiling. That attitude was widely criticized on social networks, where fans wondered what he was smiling about" (OVACION DIGITAL, 03/27/2013).

The low level of performance displayed during qualifiers for World Cup Brazil 2014, along with an attitude interpreted as not consistent with the critical situation of the team, turned Forlán into one of those major responsible for the moment of the sport's crisis, initiating the vilification process of the hero (Albuquerque, 2013).

The psychical and behavioral characteristics of the player allows for his discursive construction as a model of exemplary behavior, the most common aspects being his professionalism, commitment, education and even his social consciousness. The heroic discursive construction regarding Forlán is not the archetypal example of Uruguayan football heroes, with little relation with the collective representations traditionally valued in previous national sports heroes. 


\section{Diego Lugano: An inherited leadership.}

The captain of the national team since beginning of 2006 until World Cup Brazil 2014 has been defender Diego Lugano. The characteristics, both in relation to soccer and especially in relation to the player's psychological characteristics are highlighted as representing the typical model of the Uruguayan hero, the embodiment of the collective representation of "garra charrua" (Maneiro, 2011) and the heir of ancient victorious captains like Obdulio Varela and Jose Nasazzi.

In the press notes dealing with his biography, a leadership seed, noticeable since childhood, is pointed out in him, highlighting the importance of being captain and the representation of his peers in all the teams that he played on, from his beginning as a professional and even in non-football areas like school. His humble origins and Catholic education are also mentioned, especially linked to what would be an initial representation of social consciousness that translates into solidary behavior.

"In his childhood [...] he would also think about activities to do with friends and joining groups or how to help a classmate who could not go on a trip with them, talking to the teacher, the principal. Lugano was the spokesman, also a delegate of the Red Cross and the leader among his group of friends" (Lissardy, 2010, p. 31).

“'You noticed grim realities. People that were not doing so well. That, plus the fact that I went to Catholic school where we did spiritual retreats and benefit activities. My grandmother took me to church every Sunday [...]. I think all that generates a social awareness in you" (Lissardy, 2010, p. 31).

Throughout his career, the appearance of obstacles and how he overcame them through hard work and perseverance is mentioned as a constant theme, which fits into what Campbell (1997) described as the successive tests of the hero candidate's courage.

In this sense, it is mentioned how he was released from his first team (Nacional) and traded to a smaller team, from which, after good performances, he ended up at the São Paulo Futebol Clube. His subsequent arrival at the Brazilian club, which was in a deep crisis, and being a stranger to the crowd that questioned his arrival were more of these tests. In this regard, it is pointed out that he had to train several extra hours every day to demonstrate his value as a positive addition to the team.

Arriving at São Paulo, Lugano experienced the biggest test of his convictions. Nobody knew him and everyone asked who he was, where had he come from. He multiplied his effort, because he wanted to prove everyone wrong. He arrived three hours before practice and stayed three hours after [...]. because of his training and perseverance, he made a name [for himself]. But above all, because of his conviction. (Lissardy, 2010. p. 36)

The reward for these sacrifices came along as he earned important trophies (Brasileirão, Libertadores Cup, FIFA Club World Club's Cup is 2005), but mainly as he overcame the initial mistrust and became an idol to his fans because of his effort and commitment.

Precisely, the "garra" displayed during games is highlighted as his main virtue and allows him to be compared to previous captains of national teams, who, without having special technical virtuosity or speed, were highlighted from a psychical aspect. This link between Lugano and former Uruguayan captains is observed in all periods analyzed and also mentioned by international press, discursively constructing the player as a hero and globally recognizing him as an archetype of the Uruguayan soccer player.

"In the defenders' line, we can highlight the presence and leadership of Diego Lugano. The blonde center represents the historical captains of the Celeste team: high tempered, strong and with a notorious presence" (FIFA, 06/10/2010).

"We have a hell of a Captain. A courageous and rebellious soccer player who was forging his influence among peers by leading by example" (EL PAÍS, PUBLICACION LA BIBLIA DEL MUNDIAL, pp 15, 2010). 
"The captaincy suits him wonderfully, he marked the territory from the beginning [...]. Lugano influences both his peers and rivals" (OVACION DIGITAL, 10/08/2011).

Apart from his football characteristics, his leadership and influence over the rest of the team, his peer representation, legitimized by his fellow teammates on different levels and with different actors (coaches, officials, journalists), are pointed out. These elements often stand out as proof of being a "captain, like the ancients", an expectation that the player himself wanted to meet.

"There were several team players who explained how Lugano calmed them when they were upset about some destructive criticism received, how he tried to change the image of Uruguayan players" (Lissardy, 2010, p. 40).

"The captain is the captain. Who is going to say something inappropriate or give him a dirty look if some members of this squad do not even call him by his name?" (OVACION DIGITAL, 08/10/2011).

"It's not easy to take the role of captain in this process. It requires personality, an ability to command, but also respect and the ability to be respected by everyone [...]. Diego Lugano is moved by putting on that yellow bracelet. And he wears it proudly, trying to continue the dynasty of the great captains of history, those who filled pages and pages of glory" (ANUARIO OVACION, pp. 14, 2011).

"The issue of leadership is natural, because there are many things that are not acquired from a store [...]. The aspiration I had was that of being a captain like the ancients, adapted to modern times," stated Lugano" (ESPECIAL OVACION CAMINO AL MUNDIAL, pp. 16, 2014).

Because of this leadership, conviction and tenacity to overcome obstacles, Lugano is presented as a model for socially desirable behavior, used by several advertising companies who choose him as their frontman, leveraging his status as a "celebrity" (Jackson, 2001).

His image is also used by the Uruguayan government as the star in a series of official campaigns that attempts, using the player, to promote the value of national cohesion among the population in pursuit of a common goal ${ }^{5}$.

As occurred with Forlán, after obtaining the CA2011, Lugano begins to experience a lasting inactivity and low sports performances. After being sold from Turkish Fenerbahce (where he played for four seasons) to Paris Saint-Germain of France, he suffered a series of injuries, couldn't play regularly and ends up being lent to various clubs (Malaga, West Bromwich Albion) where he couldn't gain continuity either.

As a result of this inactivity, his performance in the national team also shows a significant decline, making no defensive errors and appearing as slow and lacking coordination according to the level of demand of the competition, which is pointed out by national press.

"The performance of individuals has notoriously declined [...]. like captain Diego Lugano, with little activity since moving to Paris Saint Germain” (OVACION DIGITAL, 10/11/2012).

"The President of the Uruguayan Football Association directed the following at Diego Lugano:

"I think that more than the aging, the most important thing is that players actually play in their clubs. Our captain is feeling the inactivity and if he does not get a team where he can play, I think it will be difficult for him to continue playing for the national team" (INFOBAE; 07/15/2012).

These criticisms were maintained throughout all qualifiers for World Cup Brazil 2014, coinciding with the inactivity of the player at his clubs. However, they were aimed strictly at issues related to soccer.

\footnotetext{
${ }^{5}$ These references can be seen at https://www.youtube.com/watch?v=S74LxfLT3C8 and
} https://www.youtube.com/watch?v=03bJlbsuSU4. Accessed 10/02/14 
After the away defeat by Chile, Lugano gave a number of press statements that were widely criticized by other players, journalists and former players, who questioned his actions as captain and team representative.

"We got ourselves into his situation and we have to get ourselves out of it. Whoever does not feel strong enough to do it better get off [the team]". These words of captain Diego Lugano only added fuel to the fire. Not just a few people believe that the captain should have spoken in the privacy of the locker room and not in public" (OVACION DIGITAL, 03/27/2013).

"Lugano's statement seems to impact what have been key features among the team: a low profile, professionalism and group management since 2006. One of the first that came to criticize Lugano was none other than his predecessor, former captain Paolo Montero: "He may have his reasons. He is, as they say, the captain, the reference. I do not want to compare or generate controversy, but I was always of the idea that things are to be said in the locker room" (LA REPUBLICA, 04/02/2013).

"The former goalkeeper of the Uruguayan national team, Fernando Alvez, also criticized captain Diego Lugano. 'We had to stand up to the fact that it was said that this national team was the best group in 40 years. At the first opportunity, they began to show their true colors [...]. A great captain fixes things in the locker room without anyone knowing. Now I think he may have lost the respect of his teammates ", (www.goal.com, 04/01/2013)

As can be seen, the reviews on his statements not only question his actions as captain, but place his legitimacy under shadow of doubt with the rest of the team and even suggests a rupture of the internal cohesion within the group.

Apart from press commentaries, censorship of his statements by not fitting with what is considered to be the attitude of a "great captain", pointed out precisely by former captains of the national team, is a crucial point in the vilification of Lugano as a figure and questions his role as heir to the ancient sports heroes.

\section{Luis Suárez: Overcoming challenges}

Still considered an emerging promise in World Cup 2010, Luis Suárez consolidated himself in American Cup 2011, was awarded as the best player of the tournament, and soon became a fundamental part of the Uruguayan team in the qualifiers for World Cup 2014, a competition during which he surpassed Diego Forlán to become the historical scorer of the national team.

Looking at the discursive construction around Luis Suárez' biography, we can see that he is presented as an almost perfect hero model with the features that were outlined in the previous section.

A childhood developed under a framework of material and emotional deprivation, traumatic movements from his small hometown to the country's capital city, his parents' separation, little discipline to train and the temptation to prematurely quit his football career are highlighted as emerging tests required to be overcome in order to achieve the condition of hero. Overcoming these, built the character and strengthened the individual to become redemptive hero of his community.

In this sense, the obstacles experienced are presented as embedded learning that influenced the subsequent actions that his experiences during childhood and adolescence may have shaped his character in the game. In line with the argument expressed for cases such as Romario (Helal, 2003) or Maradona (Archetti, 2001), humble social origins almost instinctively create the desire to win that would be superior to that of athletes born in more privileged realities.

"Luis hadn't had an easy life, he was the youngest of seven brothers. "We were a family that never had a choice at all. I never had the possibility to tell my mother 'I want those sneakers and buy them' [...] when he was seven years old, his family moved to the capital, at nine his parents separated and he rebelled against everything" (LISSARDY, 2010, pp. 124- 127). 
"Suárez entered the English league with the same decision that he stopped what would have been the last ball of the World Cup for Uruguay. He used the same strength with which he change the course of his life, when at age 15 he set himself a goal to succeed in football. With patience and, above all, commitment, Luis Suárez has taken every stone that fate has put on his road and has now conquered the world with goals" (ANUARIO OVACION, pp. 25, 2011).

The ability to overcome family conflicts and the material difficulties he experienced in childhood and youth is often attributed to Sofia Balbi, with whom the player began a relationship at age 15 that continues today. Sofia's move with her family to live in Spain was the factor that motivated Suárez in his desire to succeed in professional football to reach European Leagues. This story, repeated in various media, and supported by Luis and Sofia themselves, introduces the character of a muse described by Campbell (1997) as a motivation for action and final prize of the hero's journey.

"It was then, at age 16, when Sofia went to Spain, that he felt lost and said he had to get up to professional football [...]. His total desire to reach Europe was put on his feet and he began kicking with all his strength, in pursuit of this goal. Because that could be the passport to Europe, to Sofia" (Lissardy, 2010, p. 129).

It was during World Cup 2010 when Suárez experienced the first episode that would rank him as a national football hero. In the last action of overtime in the quarterfinals match against Ghana, Suárez blocked a goal by stopping the ball with his hand on the goal line. This action placed Luis Suárez as a hero, owner of a special instinct and willing to make a sacrifice to help his team if necessary.

The impacts of such an action were diverse, while at a national level it was classified as an instinctive act of altruism, the international press condemned it as a serious violation of fair play and more severe penalties were demanded. As happened on later occasions, this attack on the new hero allowed the Uruguayan population and press to exacerbate nationalism and join together in his defense.

"He was having a great World Cup, but needed one of those moments that transform a person from being a great player into a national idol [...]. "It was the circumstances of the moment, I had no other situation, I [had] the 'hand of god' now" stated Suarez" (Diario OLE, 07/09/2010).

"If the ball passes, World Cup is over. It takes a last resource, a last chance. This is how Suárez was taught to play, so he had no doubts" (Impedimento.org, 07/02/2010).

"The coach of Ghana, Serbian Milovan Rajevac, acknowledged he was still upset because of Luis Suárez' hand, whom he described as a "cheater" [...]. "Some say that Suarez is a hero and now he is proud. He is not a hero, he is a cheater.. What hand of God? It was the devil's hand [...]. FIFA should change the rules after this fraud. The referees should award the goal and not score a penalty if someone saves the ball with his hand on the line as it happened" stated Rajevac"(OVACION DIGITAL, 07/09/2010).

"People's reactions sometimes do not have much explanation. It was an incident of the game [...]. According to Tábarez, it has impacted "some tendentious interpretation of certain European press, namely English, which encouraged this repercussion" because of certain media” (OVACION DIGITAL, 07/11/2010).

The massive popular reception of the Uruguayan team after the World Cup, and the special ovation received by Suárez with chants precisely recalling the hand incident, demonstrate the importance of it to start consolidating his figure as a hero, which would end up occurring in American Cup 2011, where he converted four goals and was named player of the tournament.

In that year, 2011, he arrived at Liverpool F.C. from the English Premier League, where for over three years he experienced a series of soccer and extra-soccer situations that transformed him in a constant figure on the newspapers. While his influence on the team was increasing, Suárez was involved in two specific 
incidents of great repercussion: accusations of racism by player Patrice Evra, in late 2011 and a deliberate bite to player Branislav Ivanovic in 2012, which generated bans of eight and ten games, respectively.

These incidents, along with certain characteristics of his playing style such as simulations, excessive protests and gestures, transform Suárez in one of the most hated players in the world, being criticized even by England's Prime Minister and FIFA officials. ${ }^{6}$ The strength of these critics provokes a fierce defense of the player by the national press as well as statements of support from politicians and sports officials.

"According to the site, Suárez is the most hated player in world soccer. First, discriminatory words addressed to Evra. Then an intentional bite on Ivanovic, a Chelsea defender. These actions lead Luis Suárez, to the top spot as the most hated player in world soccer, promoted by the US site Bleacher Report" (PLACAR, 10/24/2013).

"Luis Suárez was dismissed from the Liverpool squad and lost all support in England. Players and journalists accuse him of being a "mercenary", a "toxic player" with a "superiority complex" and having "DNA prone to deception" [...]. A talent as a soccer player unfortunately represents much of the darkest features of the game: Physical and verbal attacks on rivals, deceit, lack of respect for contracts, greed and the belief that everything revolves around him. Suárez is the model of a modern mercenary" (MONTEVIDEO PORTAL, 08/08/2010).

"Uruguayan President Jose "Pepe" Mujica said yesterday that star Luis Suárez is "not racist" and expressed his "solidarity" with a child who "suffered poverty and is far from having received a formal education or training in diplomatic protocol. He is great on a soccer field because has the wonderful miracle of that art and does not deserve the media pressure" [...]. The support of Mujica adds to that received by Suárez from his fellow Uruguayan national teammates and the president of the Uruguayan Football Association (AUF), Sebastian Bauza" (LA REPUBLICA, 02/17/2012).

The defense of his actions by public figures is discursively justified by assuming that the attacks are disproportionate and unfair as well as by the player's social origin. This polarization of Luis Suárez as a figure denotes meanings that transcend football and establish him as a symbol of the Uruguayan national self-image.

In the recent World Cup Brazil 2014, Luis Suárez was a decisive player on the national team. Coming back from an injury due to which he lost the first game, he scored two goals against England, being highlighted in social networks and even compared to the figure of national hero José Artigas.

Later on, he would be involved in another controversy after biting the shoulder of Italian defender Chiellini in the game between the two teams. The supports and criticisms received after the confirmation of the sanction would consolidate Suárez' figure as an Uruguayan national hero, and a villain, hated by the rest of the soccer world.

The reactions of the press are in line with the traditional self-image for which Uruguay is constantly undermined intentionally in global tournaments as it is not economically viable that the country achieves good results. In this sense, it is suggested that Brazilian players would commemorate the ban because they would have fear of a possible confrontation with Uruguay, according to the supposed latency of the "Maracanaço" among Brazilian people.

"He is injured, he operates without fear of a more serious injury, he runs, makes a goal, keeps running, cramps, makes another goal. But he also reacts badly and wrong, bites, gets into trouble, asks forgiveness and gets in trouble again. All that makes him an unique player. Uruguayans love him and are willing to forgive those other things. But some people only look at

${ }^{6}$ See http://www.montevideo.com.uy/auc.aspx?198907,1,1149y

http://www.mundodeportivo.com/20121011/futbol/internacional/hasta-la-fifa-critica-a-luissuarez_54352878407.html Accessed 09/10/14 
those other things. And that is something Suárez did not quite learn" (OVACION DIGITAL, 06/28/2014).

"Shoot against Luis Suarez [...]. It was predictable. The huge ban by FIFA of Luis Suárez with all the media pressure leaves the feeling that they had a personal problem with the Uruguayan striker and the goal was his disposal. They got it their way" (OVACION DIGITAL, 06/28/2014).

"Luis Suarez was condemned by the media [...] he was found guilty long before seeing the video and the incident. Brazil got rid of him. And the British and Italians celebrated. Everyone was happy, and FIFA, according to its history, bows to the powerful". (OVACION DIGITAL, 06/27/2014).

"The evening after the triumph of Uruguay over Italy, the World Cup disappeared from the sports channels. There were no further analysis, goals, or comments. The premise was kill Suárez' [...]. Campaign? Sure!! And as Brazilian journal Folha headlines in its sport section, 'Ghosts having fun' with a huge photo of Uruguayan fans celebrating after the end of the match against Italy. That is the premise. Get Suárez out of the World Cup, or at least suspend him two games [...]. Just in case Uruguay has to play against Brazil” (OVACION DIGITAL, 06/262014).

To sum up, the discourses about Luis Suárez places him as a typical sports hero model according to the mythic structure described by Campbell (1997). Coming from a negative socio-economic position and motivated by a muse, he overcame the various challenges and tests in his path (injuries, controversies) and through football he rescues his community. His sports and psychical characteristics highlighted by the media (unpredictability, constant desire for improvement, insistence) are presented as a synthesis of the representation of the "garra charrua" which makes him an important figure for the expression of the Uruguayan self-image.

\section{Óscar Tábarez: The equilibrated "Maestro":}

When Óscar W. Tábarez was named coach of the national team in 2006, there was a measured expectation. According to recent history, the prospect of an extended contract with the possibility of developing a project in a medium term, was not common for the national team. However, the coach continues to lead the process and after World Cup Brazil 2014 and has renewed his contract until 2018, setting a record of permanence in office.

The triumphs he obtained during 2010-2013 were discursively constructed as a result of an innovative work process. Much of this success is attributed to the personal and professional characteristics of Tábarez that makes him a model of socially desirable behavior. In this sense, various biographical materials and interviews use their academic education degree as a teacher ("maestro" in Spanish) to infer from it a supposed wisdom and knowledge on managing human groups, comparing, in several press notes, the national team players with students.

"When he stopped playing football at age 31, he devoted himself only for a few years to teach in schools [...]. And it was the same "maestro" who, much later, would act with the national team" (Lissardy, 2010, p. 324).

"[...] Beyond his condition of teacher, Óscar Washington Tábarez was a "maestro" from various angles, and also when setting the team, choosing the players and capture the idea to perform. And he also remains a maestro when it comes to planning games and choosing the players. He had zero failure in the test of soccer where tactics and strategy become confusing and comple" (ANUARIO OVACION, pp. 30, 2011). 
"The best coach: Óscar Washington Tábarez. A Maestro among students, humbleness, knowledge, experience, a coach who inspires respect from his players. An example to follow" (ESPN, 07/26/2011).

The prevailing rationality in the national team process with regard to the establishment of objectives, medium- and long-term planning, and specific actions to achieve them, is presented by the sports press as a radical change in the national team working methodology, where improvisation and lack of coordination between the various agents would have prevailed until 2006. The discursively established symbiosis between these attributes of the national team process with certain personal characteristics (patience, intelligence) placed Tábarez as the architect of this change and main person responsible for the success in a discourse shared by both national and international press.

"Planning, common sense, order and hard work to start. Then perseverance and conviction despite adversity. These bases built up the whole structure that allowed the process of Tábarez to reach fourth place in South Africa in 2010" (EL OBSERVADOR AÑO Q VOLVIO A LATIR LA CELESTE, 2010).

"It was the triumph of the seriousness of a planning process. The "maestro" Tábarez summed up the spirit of this team. The maker of a group that had his seal. In his style, without a doubt, the excellent Uruguayan management in the World Cup can be summarized. His journey was the reward" (EL GRAFICO, LIBRO DE COLECCIÓN 4).

"Coherence, conviction, planning and personality accompanied Tábarez who, with the wisdom of past experience, led the way" (CONMEBOL, August 2011).

"Today, Uruguay has international team that knows how to play, with a great dose of youth and some veterans, coached by a man with thirty years' experience. The results are a correlate of his wisdom, moderation and balance. He has not only returned Uruguay to a place of privilege, but also has transformed a national team through a large project. He is the great architect of the change" (CONMEBOL, October 2011).

In addition to the strictly soccer considerations and his virtues in managing human groups supposedly resulting from his academic training, discursive constructions of Tábarez highlight the various national and international awards in cultural and political spheres. These distinctions place him as a model of exemplary behavior.

"The Uruguayan government on Tuesday distinguished the national soccer coach Óscar Washington Tábarez with a special Presidency prize and initiated his candidacy as a global ambassador for the sport at Unesco" (ESPN, 26/07/2011).

"Among many awards and recognitions, Tábarez received a very special one from the National Academy of Letters [...]. The measure and correctness of the coach was subject to recognition not just in our country. "You and your players personified core values of Uruguayan culture on the great international stage, taught at the public school you know so well" (EL GRAFICO LIBRO DE COLECCIÓN 4, pp. 45, 2010).

As occurred with other heroes, the technical and psychic capacities highlighted in moments of success were severely questioned when results were negative.

A group of influential journalists and several supporters accused Tábarez of not understanding and therefore not respecting the tradition of Uruguayan soccer and specifically the mentality of national players, trying to equate them with European players who would be "essentially" different. These reviews show the strength of collective representations in the construction of hegemonic images of the national team and its typical player as opposed to an "other", which is the European or "first world" soccer player.

The alleged stubbornness of Tábarez and his determination to keep certain players who do not perform well (Forlán and Lugano being the most notorious cases) is also pointed out, accusing the coach of making an insufficient renewal of the team which would lead to a predictable playing style. 
"I see what everyone sees," said Óscar Tábarez in the last press conference before playing against Bolivia. It's a pity he did not act to change what he saw, because this moment had been announced. It was clear: "maestro" Tábarez failed. Because it was not yesterday that Uruguay began to lose defensive consistency. It was not yesterday that Diego Forlán was no longer the game generator that the team needed. He did not answer as a coach to the problems presented. And now, if he doesn't change, he must be changed" (OVACION DIGITAL, 10/15/2012).

Also, beyond this soccer-related criticism, strong attacks were made on his ethical integrity, coming from an episode of extortion and a scheme of cash larceny from an old maid, with whom he was accused of having an extra-marital affair. Despite being an episode of his private life, the fact that he initially lied in the court trial by denying the relationship brought question to the moral image built on the coach's figure.

"An attitude like the one he adopted was not expected from Mr. Tábarez, owner of a broad general education with a teaching degree," wrote Judge Homero Da Costa in the document that confirms the sentence to his former maid. The judge criticized the coach for "delaying" the investigation by not admitting his relationship with the maid" (MONTEVIDEOPORTAL, 02/14/2014).

In turn, Óscar Tábarez' figure was also questioned from the political sphere for his public affiliation to the governing political party (Frente Amplio). The sports results were questioned by opposition parties through their communication organs, which cast a doubt on Tábarez' work, considering he had a plethora of exceptional support and still couldn't achieve expressive results.

\begin{abstract}
"Tábarez' work begins to be a great deception [...] the "Maestro" Tábarez enjoys popular support, has government backing, has the support of the soccer authorities, has "good press" and, for seven years had managed all national teams, an absolutely extraordinary deed in Uruguayan football. Besides, he earns a fortune each month. No other coach has had these advantages and yet the results are as mediocre as those of his predecessors" (ARTICULO CORREO DE LOS VIERNES, 10/13/2012).
\end{abstract}

"He fully represents the Uruguay of his time: a country that complies with little, that is increasingly less demanding and gets mediocre results, which implies that the "process" on which Tábarez has talked endlessly - flattering his own work - was destined to avoid what is now pitifully shown: few goals, no game creation, weak defense. What Process?" (ARTICULO CORREO DE LOS VIERNES, 10/13/2012).

\title{
Final Considerations
}

The agonistic feature of soccer allows the media construction of not only celebrities but also sports heroes. The central role soccer has historically occupied in Uruguay leads these players to become important models of behavior in the socialization process and everyday life of its inhabitants. In this sense, in each of the members of the national team presented by the media as heroes, a number of characteristics stand out that are valued positively and presented as role models: professionalism and perseverance (Forlán); leadership and hard work (Lugano); defiance and resilience (Suarez); intelligence and moderation (Tábarez).

These attributes are constitutive of both traditional collective representations of Uruguayan soccer as "mísitic" and "garra charrua" as well as attributes displayed as positive differentials of the current national team process (planning, rationality). Thus, the combination of these elements can discursively transmit an ideal of a nation through soccer.

However, these virtues are strongly questioned when sports results don't meet the expectations, through a vilification process of the heroes that proves the dynamism of collective representations and evidences the socially-constructed character of these figures, whose virtues can be both exalted and questioned following very variable events, "[...] such as in sports competitions and personal situations that are made public". 
The characteristics discursively alleged of the sports heroes' construction process and their later vilification indicates aspects valuable to Uruguayan society and we believe that its study may be considered a relevant input for reflecting on the national identity of that country.

\section{REFERENCES}

Albuqerque, E. (2013). A midia e o mito do Herói: analisando as matérias do caderno de esportes da folha de São Paulo a partir do caso Ronaldo (2008-2011)/ The media and myth of Hero: analyzing the materials of Folha São Paulo sports section from Ronaldo case (2008-2011). Masters Thesis. Universidade Federal de Paraná: Curitiba.

Archetti, E. (2001). The spectacle of a heroic life: the case of Diego Maradona en Jackson, S: Sport Stars: The Cultural Politics of Sporting Celebrity. New York: Routledge.

Berger, P. \& Luckman, T. (1986). The Social construction of reality. Buenos Aires: Amorrortu.

Campbell, J. (1997). O heroi das mil faces /The thousand-faces hero/. São Paulo: Cultrix/ Pensamento.

Coakley, J. (2007). Sports in Society: issues and controversies. $9^{\text {th }}$ edition, New York: Mc Graw Hill.

Da Matta, R. (1982). Universo do futebol. Esporte e Sociedade Brasileira/ Sports Universe. Brazilian society and sports. Rio de Janeiro: Edições Pinakotheque.

Durkheim, E. (2008). Formas elementares de la vida religiosa/ The elementary forms of religious life: Colofón, México D.F.

Dyer, R. (1979). Stars. London: British Film Institute.

EL PAIS Retrieved 10/03/2015 from http://historico.elpais.com.uy

EL OBSERVADOR (2010) El año que volvió a latir la celeste/ The year celeste came to beat back Journal/. pp. 3-100, Montevideo.

Flick, U. (2004). Uma introdução à pesquisa qualitative/ An Introduction to qualitative research/. Porto Alegre: Bookman.

Helal, R. (2003). Idolatría e malandragem: a cultura brasileira na biografia de Romario/ Idolatry and trickery: the Brazilian culture in the biography of Romario/ In Alabarces, P. Futbologies, Footbal, identity and violence in Latin America. Buenos Aires: CLACSO.

Jackson, S. (2001). Sport Stars: The Cultural Politics of Sporting Celebrity. New York: Routledge.

Kellner, D. (2001). The culture of media. São Paulo: EDUSC.

Lissardy, A. (2010). Vamos que vamos: Un equipo, un país /Vamos que vamos: One team, one country/. Montevideo: Santillana.

Maneiro, C. (2011). ¿Resurgir Celeste?: Mitos y Representaciones Colectivas en torno a la actuación uruguaya en Sudáfrica 2010/Celeste Resurgence: Myths and Collective Representations around a Uruguayan performance in South Africa 2010 , 224-236. Montevideo: Journal Encuentros Uruguayos Na 4.

OVACION (2010) Anuario 2010/ Yearbook 2010. Ovacion Journal EL PAIS, pp. 2-120.

OVACION (2011) Anuario 2011/ Yearbook 2011. Ovacion Journal EL PAIS, pp. 2-120

Ovacion Digital: Retrieved 10/03/2015 from www.historico.ovacion.com.uy

Ribeiro, L .(2007). Football and Globalization, São Paulo, Fontoura.

Road To World Cup 2014 (December 2013), Ovacion Journal EL PAIS, pp. 2-90.

Rubio, K. (2001). O atleta e o mito do herói: o imaginário esportivo contemporâneo/ The athlete and the hero myth: contemporary sports imagery. São Paulo Casa do Psicólogo.

El Grafico (2010) Libro de coleccion $\mathrm{N}^{\mathrm{0}} 4$ / Special Edition $\mathrm{N}^{\circ} 4$, Montevideo .

Soares, A. (2000). História e a invençao de tradiçoes no futebol brasileiro History and invention of traditions in Brazilian football in ALABARCES, Pablo: Goal Danger. Buenos Aires: CLACSO.

AUTHOR'S ADDRESS:

Wanderley Marchi Jr.

Universidade Federal do Paraná

Setor de Ciências Biológicas, Departamento de Educação Física

Rua Coração de Maria, BR 116, Km 95, nº 92

Jardim Botânico

80215370 - Curitiba, PR - Brasil

Email: marchijr@gmail.com 